\title{
Hepatitis D Virus Infection Among Hepatitis B Surface Antigen Carriers and in "Isolated anti-HBc" Antibodies Profile in Central Tunisia
}

\author{
Salma Mhalla, ${ }^{1,2,}$ Yosr Kadri, ${ }^{2}$ Sana Alibi, ${ }^{1}$ Amel Letaief, ${ }^{3}$ Jalel Boukadida, and Naila Hannachi ${ }^{1}$ \\ ${ }^{1}$ Laboratory of Microbiology and Immunology, F. Hached Teaching Hospital, (UR12SP34) University of Sousse, Sousse, Tunisia \\ ${ }_{2}^{2}$ Department of Microbiology, Fattouma Bourguiba Teaching Hospital, University of Monastir, Monastir, Tunisia \\ 3 Department of Infectious Disease, F. Hached Teaching Hospital, University of Sousse, Sousse, Tunisia \\ *Corresponding Author: Salma Mhalla, Department of Microbiology, Fattouma Bourguiba Teaching Hospital, University of Monastir, Monastir, Tunisia. E-mail: smhalla@ \\ gmail.com
}

Received 2015 September 3; Revised 2015 October 31; Accepted 2015 December 4.

\begin{abstract}
Background: Hepatitis D Virus (HDV) causes accelerated liver diseases in patients with Hepatitis B Virus (HBV) infection. There is lack of data about its prevalence, related risk factors and interaction with HBV carriers in our country.

Objectives: The aim of this study was to estimate the prevalence of hepatitis delta and associated risk factors among Hepatitis B surface antigen (HBsAg) and "isolated anti-HBc" profile carriers in central Tunisia.

Patients and Methods: In this cross-sectional study, 540 patients with positive HBsAg and 109 "isolated anti-HBc" profile receiving care in a teaching hospital were tested for the presence of HDV serum-markers using commercially available enzyme immunoassay kit. HBV-DNA was detected by nested PCR in "isolated anti-HBc" profile group.

Results: Prevalence of HDV was 8.1\% in HBsAg carriers group, but it was significantly higher in active than inactive hepatitis (30.2\% and $4.5 \%$, respectively, $\mathrm{OR}=9,95 \% \mathrm{CI}:$ [4.48-18.58]). There was no significant association between studied risk factors and HDV infection. In the "isolated anti-HBc" profile group, prevalence of HDV was 4.6\% and HBV-DNA had negative result in all patients with positive results for HDV. Conclusions: Although HDV had low prevalence in our area, it is vital to plan preventive strategies for HDV spread as well as HBV prevention. It is particularly important to suspect HDV infection in active HBV carriers to manage a particularly severe dual infection. HDV infection should be suspected even in negative HBsAg patients having "isolated anti-HBc" profile.
\end{abstract}

Keywords: Hepatitis Delta Virus, Prevalence, Risk Factors, Asymptomatic Infection, Tunisia

\section{Background}

Hepatitis D is a major global health problem affecting 15 to 20 million individuals worldwide $(1,2)$. Hepatitis $\mathrm{D}$ virus (HDV) is a small defective RNA virus dependent on Hepatitis B virus (HBV) for its replication and expression (3). The global prevalence of HDV is poorly known due to lack of studies in several parts of the world $(4,5)$. It is estimated that $5-20 \%$ of Hepatitis B surface antigen (HBsAg) carriers are co-infected with HDV. HDV infection results in more severe chronic hepatitis $B$ and occasionally fulminant form of acute hepatitis in co-infected patients (6). Dual HDV-HBV infection results in a 2 -fold increase in mortality and a more rapid progression to cirrhosis and hepatocellular carcinoma compared with HBV infection without HDV $(1,4,7)$.

Several cross-sectional studies showed that HDV infection is frequently associated with suppressed HBV replication, reducing the rate of HBV DNA and with fluctuation of HBsAg production $(8,9)$. Many Tunisian studies have been conducted to determine epidemiology and risk factors of HBV infection (10-12). HDV infection and its risk factors have been little studied in our country.

\section{Objectives}

The aim of this study was to estimate the prevalence and main related risk factors of HDV infection in the center of Tunisia in two groups of patients with different HBV serum markers.

\section{Patients and Methods}

\subsection{Population}

In this cross-sectional study, 649 patients attending Farhat HACHED hospital for known HBV infection or systematic screening were included. Patients' sera had reached the laboratory of virology between January 2011 and April 2012. There were two groups of patients; 540 HBsAg positive carriers and 109 "isolated anti-HBc" antibodies carriers with positive anti-HBc antibodies and negative HBsAg and anti-HBs antibodies (Table 1 ).

Informed consent was obtained from each patient and a questionnaire was filled including the following data: age, gender, history of blood transfusion or scarifications, intravenous drug abuse, "high-risk" sexual behavior and history of familial hepatitis, clinical symptoms and alanine aminotransferase (ALT) elevation level. 


\subsection{Serological Tests}

Serum samples were already tested for markers of hepatitis B (HBsAg, HBeAg, anti-HBs, anti-HBc and anti-HBe antibodies) by automated microparticle enzyme immunoassay (Axsym system / Abbott@, Germany) with sensitivity of $98-100 \%$ and specificity of 97-99.5\%. Samples were then tested for anti-HDV antibodies (IgG) with third generation enzyme-linked immunosorbent assay (Globe Diagnostics@, Italy) with sensitivity and specificity of 99.8 and $100 \%$.

\subsection{Molecular Tests}

Detection of HBV DNA by polymerase chain reaction (PCR) was performed in patients with an "isolated anti$\mathrm{HBC}$ " profile and concerned two regions of the HBV genome: the pre-S and $C$ regions with a global sensitivity of $10^{3}$ copies/mL. After extraction of the DNA (QIAamp DNA Blood Mini kit; Qiagen () , amplification in the pre-S region was performed by a classical PCR according to the protocol of Lindh (13). Then, a nested PCR was performed in the $\mathrm{C}$ region according to a protocol described by $\mathrm{Al}$ hababi (14).

\subsection{Statistical Analysis}

Data analysis was performed by software Epi Info version 6.0, using Chi2 and Fisher's exact tests. A P $<0.05$ was considered statistically significant. The study protocol conformed to the ethical guidelines of the 1975 Declaration of Helsinki.

\section{Results}

Overall, 649 patients were enrolled in this study. The mean age was $36.01 \pm 11.6$ years (14 to 82 years) and male/ female ratio was about 0.7 . These patients were active carriers in 95 patients (14.6\%). HBeAg had positive result in 34 patients and all of them belonged to the first group (Table 2). Among these positive HBeAg, there were 17 cases of chronic hepatitis B, including 14 active hepatitis and 17 cases discovered during a routine screening. In the "isolated anti-HBc" profile group, the average age was $31.3 \pm 9.6$ years, gender ratio was 0.6 and $17.4 \%$ of patients had at least one clinical symptom or biological disorders (Table 2).

Of 649 patients, 49 had positive result for HDV IgG antibodies, yielding an overall seroprevalence of 7.5\%. There was no significant difference between HDV-positive and HDV-negative patients regarding sex (male/female ratio $=$ 0.7 ) and mean age (32.2 years vs. 35 years, $\mathrm{P}>0.05$ ). $\mathrm{HBeAg}$ was absent in $84 \%$ of HDV positive sera.

In the first group, the prevalence of positive HDV antibodies was $8 \%$ (44/540 patients). No significant association was observed between hepatitis D and family history of jaundice or personal history of blood transfusion or having multiple sex partners (Table 3). However, there was a significant higher rate of HDV negative status in HBsAg asymptomatic (inactive) carriers $\left(\mathrm{P}<10^{-3}, \mathrm{OR}=9\right.$, 95\% CI: [4.48-18.58]). Among patients with active hepatitis and positive HDV status, most frequent symptoms were jaundice and elevated ALT $\left(\mathrm{P}<10^{-3}\right)$ (Table 3$)$.

In the second group, 5/109 patients had positive HDV antibodies (4.6\%). These five patients had positive anti-HBe antibodies and all of them were asymptomatic; two candidates for medically assisted reproduction, two blood donors and one pregnant women. In this group, HBV DNA was detected in $4 / 109$ sera (3.6\%), but in none of the five HDV positive ones.

Table 1. General Characteristics of Studied Population ${ }^{\mathrm{a}}$

\begin{tabular}{lccc}
\hline Variables & Group 1 Positive HBsAg & Group 2 “Isolated Anti-HBc” Profile & Total \\
\hline Known chronic HBsAg carriers & $335(62)$ & 0 & $335(51.6)$ \\
\hline Systematic screened patients for HBsAg & & $35(32.1)$ & $135(21)$ \\
\hline Pregnant women & $100(18.5)$ & $44(40.4)$ & $108(16.6)$ \\
\hline Candidates for medically assisted reproduction & $64(11.9)$ & $5(4.6)$ & $27(4.1)$ \\
\hline Poly transfused & $22(4.1)$ & $8(7.3)$ & $18(2.7)$ \\
\hline Health care workers & $10(1.8)$ & $17(15.6)$ & $26(4)$ \\
\hline Blood donors & $9(1.7)$ & $109(100)$ & $649(100)$ \\
\hline Total & $540(100)$ & & \\
\hline
\end{tabular}

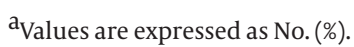


Mhalla S et al.

Table 2. Different Symptoms/Biological Disorders in the Two Studied Groups ${ }^{\mathrm{a}}$

\begin{tabular}{lccc}
\hline Variables & Group 1 HBsAg Positive $(\mathbf{n = 5 4 0})$ & Group 2 "Isolated Anti-HBc" Profile $(\mathbf{n}=\mathbf{1 0 9})$ & Total \\
\hline Asymptomatic patients & $464(86)$ & $90(82.5)$ & $554(85.4)$ \\
\hline Symptomatic patients ${ }^{\mathbf{b}}$ & $76(14)$ & $19(17.4)$ & $95(14.6)$ \\
\hline $\begin{array}{l}\text { Symptoms/biological disorders } \\
\text { Jaundice }\end{array}$ & $22(4)$ & & $25(3.8)$ \\
\hline Elevated ALT > 40, UI/L C & $55(10)$ & $3(2.7)$ & $67(10.3)$ \\
\hline Cirrhosis & $8(1.4)$ & $12(11)$ & $12(1.8)$ \\
\hline Liver function failure & $4(0.7)$ & $4(3.6)$ & $4(0.6)$ \\
\hline Positive HBeAg & $34(6.3)$ & 0 & $34(5.2)$ \\
\hline
\end{tabular}

a Values are expressed as No.(\%).

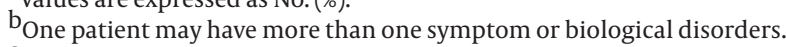

cAlanine Aminotransferase.

Table 3. Distribution of Positive HDV Antibodies According to Risk Factors and Clinical/Biological Condition Among 540 HBsAg Carriers

\begin{tabular}{|c|c|c|c|c|c|c|}
\hline \multirow[t]{2}{*}{ Variables } & \multicolumn{2}{|c|}{ Prevalence of HDVAb } & \multirow[t]{2}{*}{ Total } & \multirow[t]{2}{*}{ P Value } & \multirow[t]{2}{*}{ OR } & \multirow[t]{2}{*}{ CI 95\% } \\
\hline & Positive $(n=44)$ & Negative $(n=496)$ & & & & \\
\hline \multicolumn{7}{|l|}{ Risk factors ${ }^{a}$} \\
\hline History of hepatitis B in the family & $1(3.5)$ & $27(5.4)$ & 28 & 0.7 & 0.4 & $0.01-2.58$ \\
\hline Surgery & 0 & $20(4)$ & 20 & 0.3 & NA & NA \\
\hline Transfusions & 0 & $24(4.8)$ & 24 & 0.2 & NA & NA \\
\hline Tattoo/scarifications & $3(12.5)$ & $21(4.2)$ & 24 & 0.4 & 1.6 & $0.3-5.9$ \\
\hline Multiple sex partners & 0 & $7(1.4)$ & 7 & $>0.99$ & NA & NA \\
\hline Intravenous drug users & 0 & $2(0.4)$ & 2 & $>0.99$ & NA & NA \\
\hline \multicolumn{7}{|l|}{ Clinical/biological condition } \\
\hline Asymptomatic carriage of HBsAg & $21(4.5)$ & $443(89.3)$ & 464 & $<10^{-3}$ & 9 & $4.48-18.58$ \\
\hline Symptomatic patients ${ }^{\mathrm{b}}$ & $23(30.2)$ & $53(10.7)$ & 76 & & & \\
\hline NA Jaundice & $6(27.2)$ & $16(0.3)$ & 22 & $<10^{-3}$ & 4.7 & $1.42-13.63$ \\
\hline NA Cirrhosis & $1(12.5)$ & $7(1.4)$ & 8 & 0.49 & 1.6 & $0.03-13.11$ \\
\hline NA liver function failure & $1(25)$ & $3(0.6)$ & 4 & 0.28 & 3.8 & $0.07-48.5$ \\
\hline NA Elevated ALT > 40, UI/L & $10(18.1)$ & $45(9)$ & 55 & $<10^{-3}$ & 2.9 & $1.21-6.59$ \\
\hline Positive HBeAg & $4(11.7)$ & $30(6)$ & 34 & 0.5 & 1.5 & $0.37-4.73$ \\
\hline
\end{tabular}

Abbreviations: Ab, antibodies; ALT, alanine aminotransferase.

ane patient may have more than one risk factor.

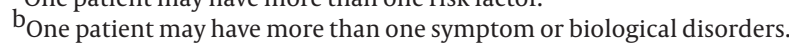

\section{Discussion}

Prevalence and risk factors of HDV infection are closely related to those of $\mathrm{HBV}(15)$. Tunisia is an intermediate endemicity area for hepatitis B, but HDV prevalence is not well known in some parts of the country $(11,16)$. In our study, the prevalence of anti-HDV antibodies in inactive HBsAg carriers was $4 \%$. When compared to previous Tunisian studies, our result confirms the declining trend of hepatitis D prevalence from 33\% in 1990 (17) and 16.1\% in 1997 (11) to $6.8 \%$ in 2009 (16). This decrease can be explained by improvements of socioeconomic conditions, awareness of transmitting viruses and above all, a better control of HBV infection and systematic vaccination since 1995. A decline in HDV infection has also been reported since the 90th in others countries with low endemicity of HBV infection such as Italy, Spain, Turkey and Taiwan (18-20). However, in the last decade the prevalence of HDV remained constant in some countries such as England and France, due to migration of subjects from endemic areas (1). In contrast, the prevalence of HDV may exceed 60\% in countries of high endemicity for HBV, such as India or center Africa $(21,22)$.

In our work, none of the studied risk factors was associated with HDV infection; although, the possibility of missing bias cannot be excluded. In Anglo-Saxon countries, the main risk factor for infection with HDV is intravenous 
addiction $(23,24)$. In endemic areas, household transmission is the most common mode of transmission for HDV, but sexual and nosocomial risk were described (25). This intra-familial contamination is probably important in our country, as it is prominent in HBV transmission $(11,12,26)$.

According to Tunisian and European data, our study showed no significant difference in HDV prevalence between the two genders $(17,27)$. Furthermore, more than $80 \%$ of HDV positive patients have negative result for HBeAg. Other studies showed similar results with up to $90 \%$ of $\mathrm{HDV}(+)$ patients having negative finding for HBeAg $(28,29)$. These findings may be due to high rate of precore region mutations, which can exceed $90 \%$ of Tunisian patients infected chronically with HBV (30-32). In addition, it has been described that HDV inhibits the expression of HBeAg through its ribozymes, which are enzymes able to destroy mRNAs that encode for Pre/C region (33).

Our data showed that patients with jaundice and elevated ALT were more likely to have HDV-positive status than inactive HBsAg carriers, which could be explained by a more severe infection in co-infected patients (HBV) HDV). As proposed in other countries such as the USA, HDV status is searched in all patients with active B hepatitis $(30,34,35)$. In our study, there was no correlation between cirrhosis, liver failure and HDV-positive status, but these two pathologies were not enough represented. Indeed, other studies conducted on a larger population of positive HDV patients, have shown rapid and frequent progression to liver cirrhosis and liver failure (34).

In the "isolated anti-HBc" profile group, the prevalence of HDV was about $4.5 \%$, which is almost similar to the level found in inactive HBsAg carrier's group. Positive HDV status may reflect either past healed co/super-infection or current co/super-infection with both viruses. HBsAg and HBV-DNA apparently fluctuate in longitudinally studied patients because of interaction and competition between $\operatorname{HDV}$ and $\operatorname{HBV}(1,8,9,35)$. Thus, occult hepatitis B associated with HDV cannot be excluded and should be searched. In our study, none of the five positive-HDV patients had detectable HBV-DNA. The use of more sensitive technique with lower threshold may allow us not to miss occult hepatitis, since HBV-DNA is often low in double infection $(8,9$, 36). Of these five patients, there was a pregnant woman and two candidates for assisted reproduction, exposed to a risk of mother to child viral transmission. Indeed, vertical transmission of HDV is possible and has been demonstrated by phylogenetic analysis of the strains of a mother and her child in Taiwan (37). Two other patients were also at high risk of HBV and HDV dissemination as they were blood donors (38). Systematic screening for anti-HBc or viral HBV-DNA in these populations could reduce the risk of spread of these two infections.

The prevalence of HDV infection in our region enhances other Tunisian data and introduces our country as a low endemicity area. It also confirms the downtrend in the prevalence of this infection in last decades. It would be interesting to complete this work by phylogenetic studies clarifying the role of family transmission in HDV infection. Regarding the severity of dual infection by HBV and HDV, we would propose that future Tunisian guidelines emphasize the relevance to test for HDV in all patients with active B hepatitis. Also not to miss HDV infection among patients with occult hepatitis B, especially in population of high risk of spread of both viruses.

\section{Footnotes}

Authors' Contribution:Study concept and design: Salma Mhalla and Naila Hannachi; acquisition of data: Salma Mhalla and Sana Alibi; analysis and interpretation of data: Salma Mhalla, Naila Hannachi and Yosr Kadri; rafting of the manuscript: Salma Mhalla; critical revision of the manuscript for important intellectual content: Naila Hannachi; statistical analysis: Salma Mhalla and Sana Alibi; administrative, technical and material support: Jalel Boukadida; study supervision: Jalel Boukadida and Amel Letaief.

Funding/Support:This study was funded by the ministry of higher education, scientific research and technology: research unit "genomic characterization of infectious agents UR12SP34”.

\section{References}

1. Rizzetto M. Hepatitis D: thirty years after. $J$ Hepatol. 2009;50(5):1043-50. doi: 10.1016/j.jhep.2009.01.004. [PubMed: 19285743]

2. Saravanan S, Velu V, Kumarasamy N, Shankar EM, Nandakumar S, Murugavel KG, et al. Seroprevalence of hepatitis delta virus infection among subjects with underlying hepatic diseases in Chennai, southern India. Trans R Soc Trop Med Hyg. 2008;102(8):793-6. doi:10.1016/j.trstmh.2008.05.001. [PubMed: 18556033]

3. Rizzetto M, Purcell RH, Gerin JL. Epidemiology of HBV-associated delta agent: geographical distribution of anti-delta and prevalence in polytransfused HBsAg carriers. Lancet. 1980;1(8180):12158. [PubMed: 6104036]

4. Lunel-Fabiani F, Mansour W, Amar AO, Aye M, Le Gal F, Malick FZ, et al. Impact of hepatitis B and delta virus co-infection on liver disease in Mauritania: a cross sectional study. J Infect. 2013;67(5):44857. doi:10.1016/j.jinf.2013.06.008. [PubMed: 23796871]

5. Amini N, Alavian SM, Kabir A, Aalaei-Andabili SH, Saiedi Hosseini SY, Rizzetto M. Prevalence of hepatitis $d$ in the eastern mediterranean region: systematic review and meta analysis. Hepat Mon. 2013;13(1):e8210. doi:10.5812/hepatmon.8210. [PubMed: 23554822]

6. Govindarajan S, Chin KP, Redeker AG, Peters RL. Fulminant B viral hepatitis: role of delta agent. Gastroenterology. 1984;86(6):141720. [PubMed: 6714570]

7. Fattovich G, Giustina G, Christensen E, Pantalena M, Zagni I, Realdi $G$, et al. Influence of hepatitis delta virus infection on morbidity and mortality in compensated cirrhosis type B. The European Concerted Action on Viral Hepatitis (Eurohep). Gut. 2000;46(3):420-6. [PubMed:10673308]

8. Schaper M, Rodriguez-Frias F, Jardi R, Tabernero D, Homs M, Ruiz G, et al. Quantitative longitudinal evaluations of hepatitis delta virus RNA and hepatitis B virus DNA shows a dynamic, complex replicative profile in chronic hepatitis B and D. J Hepatol. 2010;52(5):65864. doi:10.1016/j.jhep.2009.10.036. [PubMed: 20346531]

9. Wedemeyer H. Re-emerging interest in hepatitis delta: new insights into the dynamic interplay between HBV and HDV.J Hepatol. 2010;52(5):627-9. doi:10.1016/j.jhep.2010.02.001.[PubMed:20334947]

10. Triki H. [Epidemiology of hepatitis B virus, hepatitis $C$ virus and Delta virus in the general population and in liver cirrhosis in Tunisia].Arch Inst PasteurTunis. 1994;71(3-4):403-6. [PubMed: 8801835] 
11. Triki H, Said N, Ben Salah A, Arrouji A, Ben Ahmed F, Bouguerra A, et al. Seroepidemiology of hepatitis B, C and delta viruses in Tunisia. Trans R Soc Trop Med Hyg. 1997;91(1):11-4. [PubMed: 9093616]

12. Hannachi N, Bahri O, Mhalla S, Marzouk M, Sadraoui A, Belguith A, et al. [Hepatitis B virus infection in Tunisian pregnant women: risk factors and viral DNA levels in HBe antigen negative women]. Pathol Biol (Paris). 2009;57(3):e43-7. doi: 10.1016/j.patbio.2008.04.017. [PubMed:18513893]

13. Lindh M, Andersson AS, Gusdal A. Genotypes, nt 1858 variants, and geographic origin of hepatitis B virus--large-scale analysis using a new genotyping method. J Infect Dis. 1997;175(6):1285-93. [PubMed: 9180165]

14. Alhababi F, Sallam TA, Tong CY. The significance of 'anti-HBc only' in the clinical virology laboratory. J Clin Virol. 2003;27(2):162-9. [PubMed: 12829038]

15. Rizzetto M. Hepatitis delta: the virus and the disease. J Hepatol. 1990;11 Suppl 1:S145-8. [PubMed: 2079573]

16. Djebbi A, Rebai WK, Bahri O, Hogga N, Sadraoui A, Triki H. [Serological markers, viral RNA and genotype of hepatitis delta virus in HBs antigen positive Tunisian patients]. Pathol Biol (Paris). 2009;57(7-8):518-23. doi: 10.1016/j.patbio.2008.09.010. [PubMed: 19038509]

17. Jenhani F, Ayed K, Gorgi Y, Zoulim F, Pichoud C, Trepo C. Delta infection in chronic HBs Ag carriers in Tunisia: high prevalence in chronic asymptomatic HBs Ag carriers and in HBs Ag positive cirrhosis. Ann Trop Med Parasitol. 1990;84(4):349-53. [PubMed: 2260899]

18. Gaeta GB, Stroffolini T, Chiaramonte M, Ascione T, Stornaiuolo G, Lobello S, et al. Chronic hepatitis D: a vanishing Disease? An Italian multicenter study. Hepatology. 2000;32(4 Pt 1):824-7. doi: 10.1053/jhep.2000.17711. [PubMed:11003629]

19. Degertekin H, Yalcin K, Yakut M. The prevalence of hepatitis delta virus infection in acute and chronic liver diseases in Turkey: an analysis of clinical studies. Turk J Gastroenterol. 2006;17(1):25-34. [PubMed:16830274]

20. Huo TI, Wu JC, Lin RY, Sheng WY, Chang FY, Lee SD. Decreasing hepatitis D virus infection in Taiwan: an analysis of contributory factors. J Gastroenterol Hepatol. 1997;12(11):747-51. [PubMed: 9430041]

21. Acharya SK, Madan K, Dattagupta S, Panda SK. Viral hepatitis in India. Natl Med J India. 2006;19(4):203-17. [PubMed:17100109]

22. Makuwa M, Caron M, Souquiere S, Malonga-Mouelet G, Mahe A Kazanji M. Prevalence and genetic diversity of hepatitis B and delta viruses in pregnant women in Gabon: molecular evidence that hepatitis delta virus clade 8 originates from and is endemic in central Africa. J Clin Microbiol. 2008;46(2):754-6. doi: 10.1128| JCM.02142-07. [PubMed:18077651]

23. Mele A, Mariano A, Tosti ME, Stroffolini T, Pizzuti R, Gallo G, et al. Acute hepatitis delta virus infection in Italy: incidence and risk factors after the introduction of the universal anti-hepatitis B vaccination campaign. Clin Infect Dis. 2007;44(3):e17-24. doi: 10.1086/510433. [PubMed:17205431]

24. Bialek SR, Bower WA, Mottram K, Purchase D, Nakano T, Nainan O, et al. Risk factors for hepatitis B in an outbreak of hepatitis B and D among injection drug users. JUrban Health. 2005;82(3):468-78. doi:10.1093/jurban/jti094. [PubMed:16049202]

25. Seetlani NK, Abbas Z, Raza S, Yakoob J, Jafris W. Prevalence of hep- atitis D in HBsAg positive patients visiting liver clinics. J Pak Med Assoc. 2009;59(7):434-7. [PubMed:19579728]

26. Ben-Alaya-Bouafif N, Bahri O, Chlif S, Bettaieb I, Toumi A, Bel Haj HN, et al. Heterogeneity of hepatitis B transmission in Tunisia: risk factors for infection and chronic carriage before the introduction of a universal vaccine program. Vaccine 2010;28(19):3301-7. doi: 10.1016/j.vaccine.2010.02.101. [PubMed: 20226251]

27. Abe K, Hayakawa E, Sminov AV, Rossina AL, Ding X, Huy TT, et al. Molecular epidemiology of hepatitis B, C, D and E viruses among children in Moscow, Russia. J Clin Virol. 2004;30(1):57-61. doi: 10.1016/j.jcv.2003.08.009. [PubMed:15072755]

28. Heidrich B, Deterding K, Tillmann HL, Raupach R, Manns MP, Wedemeyer H. Virological and clinical characteristics of delta hepatitis in Central Europe. JViral Hepat. 2009;16(12):883-94. doi: 10.1111/j.1365-2893.2009.01144.x. [PubMed:19566789]

29. Ataei B, Yazdani MR, Kalantari H, Yaran M, Nokhodian Z, Javadi AA, et al. Hepatitis D virus infection in Isfahan, central Iran: Prevalence and risk factors among chronic HBV infection cases. Hepat Mon. 2011;11(4):269-72. [PubMed:22706272]

30. Triki H, Ben Slimane S, Ben Mami N, Sakka T, Ben Ammar A, Dellagi K. High circulation of hepatitis B virus (HBV) precore mutants in Tunisia, North Africa. Epidemiol Infect. 2000;125(1):169-74. [PubMed: 11057973

31. Bahri O, Cheikh I, Hajji N, Djebbi A, Maamouri N, Sadraoui A, et al. Hepatitis B genotypes, precore and core promoter mutants circulating in Tunisia. J Med Virol. 2006;78(3):353-7. doi: 10.1002 jmv.20554. [PubMed:16419125]

32. Ouneissa R, Bahri O, Alaya-Bouafif NB, Chouaieb S, Ben Yahia A, Sadraoui A, et al. Frequency and clinical significance of core promoter and precore region mutations in Tunisian patients infected chronically with hepatitis B. JMed Virol. 2012;84(11):1719-26. doi:10.1002/jmv.23394. [PubMed:22997074]

33. Wang CX, Lu YQ, Qi P, Chen LH, Han JX. Efficient inhibition of hepatitis B virus replication by hepatitis delta virus ribozymes delivered by targeting retrovirus. Virol J. 2010;7:61. doi: 10.1186/1743422X-7-61. [PubMed: 20236514]

34. Kushner T, Serper M, Kaplan DE. Delta hepatitis within the Veterans Affairs medical system in the United States: Prevalence, risk factors, and outcomes. J Hepatol. 2015;63(3):586-92. doi:10.1016/j. jhep.2015.04.025. [PubMed:25962883]

35. Celen MK, Ayaz C, Hosoglu S, Geyik MF, Ulug M. Anti-hepatitis delta virus seroprevalence and risk factors in patients with hepatitis B in Southeast Turkey. Saudi Med J. 2006;27(5):617-20. [PubMed:16680248]

36. Ghamari S, Alavian SM, Rizzetto M, Olivero A, Smedile A, Khedive A, et al. Prevalence of hepatitis delta virus (HDV) infection in chronic hepatitis B patients with unusual clinical pictures. Hepat Mon. 2013;13(8):e6731. doi: 10.5812/hepatmon.6731. [PubMed: 24098308]

37. Huang YH, Wu JC, Lu SN, Chiang TY, Chang FY, Lee SD. Phylogenetic analysis to document a common source of hepatitis D virus infection in a mother and her child. Zhonghua Yi Xue Za Zhi (Taipei).1999;62(1):28-32. [PubMed:10063709]

38. Romeo R. [Role of the hepatitis Delta virus on the pathogenesis of hepatic cirrhosis and hepatocellular carcinoma. Recent advances]. Recenti Prog Med. 2010;101(2):52-6. [PubMed: 20433000] 